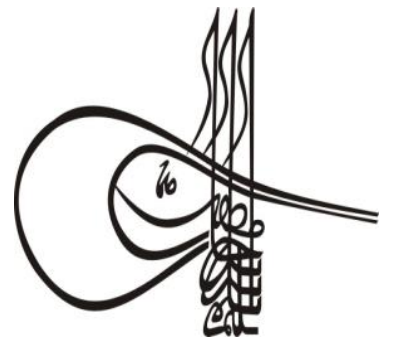

\section{Tutkigh Studies \\ Social Sciences}

Volume 14 Issue 4, 2019, p. 1563-1575

DOI: 10.29228/TurkishStudies.24811

ISSN: 2667-5617

Skopje/MACEDONIA-Ankara/TURKEY

Research Article / Araştırma Makalesi

Article Info/Makale Bilgisi

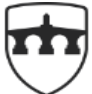

INTERNATIONAL BALKAN UNIVERSITY

EXCELLENCE FOR THE FUTURE IBU.EDU.MK

This article was checked by iThenticate.

\title{
TRANSMEDYA HİKÂYE ANLATIMI BAĞLAMINDA KRALİYET MARKASI
}

\author{
Zaliha İnci KARABACAK*
}

\begin{abstract}
öz
Markaların tüketicilerle duygusal köprüler kurmak için sıkça başvurduğu bir yöntem olarak hikâye anlatımı günümüzde geleneksel ve dijital farklı mecralar üzerinden birarada yürütülmektedir. Transmedya hikayeciliği kavramını doğuran bu süreç popüler kültürde görsel iletişim açısından büyük önem taşıyan farklı ürünlerle (film, dizi, oyun, reklam, belgesel vb.) gündeme gelmektedir. Transmedya hikâye anlatımının özellikle günümüz dijital iletişim teknolojilerini etkin olarak kullanan gençliği ifade eden dijital yerlilerin özelliklerine ve alışkanlıklarına hitap eden bir anlatım biçimi olduğu dikkati çekmektedir. Bu çalışmada transmedya hikâye anlatımı kraliyet markası bağlamında, Prens Harry ve Meghan Markle'ın Kraliyet Düğünü örnek olayı aracıı̆ğıla ele alınmaktadır. İngiliz Kraliyet ailesinin yeni evli çifti olarak Prens Harry ve Meghan ilişkilerinin başlangıcından bu yana dünya basınından yoğun ilgi görmektedir. Bu bağlamda çift, Kraliyet markası açısından da büyük önem taşımaktadır. Medyada modern bir peri masalı olarak yer bulan Kraliyet Düğünü farklı boyutlarıyla (kişiler, olaylar, mekanlar vb.) ele alınan, izleyicilerinin katılımı/etkileşimi ile zenginleşerek geleneksel ve yeni medyada paylaşılarak geniş yer bulan bir anlatı niteliğindedir. Çalışmada Kraliyet Düğünü, Jenkins'in transmedya hikâye anlatımı için sıraladığı yedi prensip (yayılabilirlik ve derinleşebilirlik, süreklilik ve çeşitlilik, dalmak ve çıkarabilmek, dünya kurmak, dizisellik, öznellik, performans) çerçevesinde değerlendirilmektedir. Çalışmanın bulguları, kraliyet markasının medyada temsilinin bir boyutunu oluşturan Kraliyet Düğününün transmedya hikâye anlatımı bağlamında Jenkins'in belirttiği özellikleri taşıdığını göstermektedir.
\end{abstract}

Anahtar Kelimeler: Transmedya, Dijital Yerliler, Transmedya Hikâye Anlatımı, Kraliyet Markası

Doç. Dr., TOBB Ekonomi ve Teknoloji Üniversitesi, Görsel İletişim Tasarımı Bölümü, E-posta: zincikarabacak@gmail.com 


\title{
ROYAL BRAND IN THE CONTEXT OF TRANSMEDIA STORYTELLING
}

\begin{abstract}
Storytelling is carried out together on different media (traditional and digital) as a method where brands frequently resort to establishing emotional bridges with consumers. The course of events which gives rise to the concept of transmedia storytelling, comes up with different products (film, series, games, ilisskiadvertising, documentary etc.) that have great importance with regard to visual communication in popular culture. Transmedia storytelling is a form of narration especially that adresses the characteristics and habits of youth called digital natives whom use today's digital communication technologies effectively. In this study, transmedia storytelling is discussed by means of Prince Harry and Meghan Markle's Royal Wedding, which is examined as case study in the context of royal brand. As the newly married couple of the British Royal family, Prince Harry and Meghan have received much attention from the world press since the beginning of their relationship. In this context, the couple is also of great importance for the Royal brand. The Royal Wedding, which has a wide place as a modern fairy tale in the media, is a narrative shared in traditional and new media, enriched with different dimensions (people, events, places, etc.) and the participation/ interaction of its audience. In this study, the Royal Wedding is evaluated within the framework of Jenkins seven principles (spreadability vs. drillability, continuity vs. multiplicity, immersion vs. extractability, worldbuilding, seriality, subjectivity, performance) The findings of the study show that the Royal Wedding, which is a dimension of the representation of the royal brand in the media, has the principles stated by Jenkins in the context of transmedia storytelling.
\end{abstract}

\section{STRUCTURED ABSTRACT}

Nowadays, it is seen that different contents (entertainment, politics, economy, art, etc.), enriched by the active participation of individuals who stand out with different identities such as audience, consumer and commentator, take place in the traditional and new media as transmedia stories. Transmedia has a wide range of popular cultural products such as film, advertising, series, computer games and documentaries which are the subject of visual communication. Transmedia storytelling, in particular, is a form of narrative that addresses digital natives who often spend time in online environments by interaction with others. In other words, digital storytelling is a current tool for digital natives who feel comfortable in the online environment of presented story by expressing themselves. UNESCO (2011) specify three main aspects of the way digital natives behave as; accessing new knowledge, networking and developing collective intelligence. Digital natives' these three main aspects have intersection points with the seven principles (spreadability vs. drillability, continuity vs. multiplicity, immersion vs. extractability, worldbuilding, seriality, subjectivity, performance) of transmedia storytelling which are outlined by Jenkins (2010a). "Spreadability and drillability" refer to the circulation of digital natives in different media platforms for accessing to 
new knowledge. "Continuity and multiplicity" contribute to the construction of the collective intelligence of digital natives who make personal touches to the different dimensions of the story on different media. "Immersion and extractability" refer to digital natives' access to new knowledge and "performance" points out the expansion of the established network.

In this study, the transmedia storytelling is examined in the context of the "Royal Brand", by the example of the "Royal Wedding" which represents this brand and takes place as a modern fairy tale in media. The Royal Wedding refers to the wedding ceremony of Prince Harry and Meghan Markle, which took place on 19 May 2018 and was shared with the "Royal Wedding" label on their official social media accounts. The news about the royal wedding has reached a wide range of audiences around the world by being widely featured on various media platforms. After marriage Prince Harry became The Duke of Sussex, and Meghan Markle became The Duchess of Sussex. In this study, the British Royal Wedding is examined within the framework of seven principles that Jenkins (2010a) has listed about transmedia storytelling.

Sky News, using the Amazon Rekognition application that provides image and video analysis, identified the famous people attending the Royal Wedding with a face reading system and shared their names and some information with the audience. These shares in the traditional and new media exemplify Jenkins' principle of "spreadability and drillability" which is emphasized in the context of transmedia storytelling.

The broadcast of different television documentaries in the years following the Royal Wedding (2018-2019), the shared webisode from the documentary called "Royal Wedding of Operation" on Natgeotv's website are related to Jenkins' the principle of "continuity and multiplicity".

In relation to the wedding of Meghan Markle and Prince Harry, different products such as posters, magnets, stamps and souvenirs were prepared. These products serve as an example of the franchise tradition that is important in the context of transmedia storytelling. These products may be associated with the principle of "immersion and extractability" that emphasized by Jenkins about transmedia storytelling.

Royal Wedding celebrations of some brands made "worldbuilding"as one of the Jenkins' transmedia principles- visible in diffent platforms. ABC News's IOS application that enables photo taking with 3D Royal wagon or with the 3D Queen's guards and the Lego's miniature Winsdor Castle prepared with 39,960 Legos for Royal Wedding can be listed as examples of "worldbuilding".

Shared photos from the official Instagram account of Sussex Royal of the Royal Wedding that have not been published before, remind of Jenkins' principle of "seriality". The photos are published on the anniversary of the Royal Wedding.

Some cases connected with Royal Wedding, in which viewers focus on the experiences and perspectives of the secondary characters of the story, illustrate Jenkins' the principle of "subjectivity". For instance, Prince Harry's former girlfriend Chelsy Davy was among the guests of the Royal Wedding. Her facial expressions during the ceremony were shared by many people in a humorous manner on social media. Also as the 
bride's father, Thomas Markle, remained on the agenda of this story with various media reports about Royal Wedding.

In the matter of expressing the participation of fans to the story in various ways, Jenkins emphasizes the principle of "performance". Meghan Markle's holiday photo taken in front of Buckingham Palace in England at the age of 15 is shared by many people on social media. The principle of performance is exemplified by this high share ratio.

The findings of the study show that the Royal Wedding, which is considered within the framework of Jenkins' (2010a) seven main principles, has the listed characteristics related to the transmedia storytelling. The Royal Wedding made dreams come true with the testimony of billions of people around the world who follow the wedding from different channels such as TV, social media and radio. The Royal Wedding, which is described as a modern fairy tale, can be expressed as a transmedia story that is enriched by the participation of the audience on different media platforms.

Keywords: Transmedia, Digital Natives, Transmedia Storytelling, Royal Brand

\section{Giriş}

İletişim teknolojilerinin gelişimine koşut biçimde çeşitli mecralardan paylaşıma açılan farklı nitelikteki (eğlence, siyaset, ekonomi, sanat vb.) içerikler; izleyici, tüketici, yorumlayıcı gibi farklı kimlikleri ile öne çıkan bireylerin aktif katılımı ile zenginleşen birer transmedya hikâye anlatısı olarak karşımıza çıkmaktadır. Tüketim endüstrisine konu olan kuruluşlar, kültürel içerikler (sinema, dizi, kitap vb.), ünlüler gibi çeşitli marka örnekleri üzerinden hayat bulan transmedya hikayelerin birçok yönüyle, dijital iletişim teknolojilerinin kullanımını yaşam pratiği olarak içselleştiren gençlere güncel betimlemesiyle dijital yerlilere hitap eden bir anlatı biçimi olduğu görülmektedir. Bu çalışmada transmedya hikâye anlatımı kraliyet markası bağlamında, bu markayı temsil eden ve farklı mecralarda modern peri masalı olarak yer bulan Kraliyet Dügünü ${ }^{1}$ örnek olayı üzerinden Jenkins'in (2010a) transmedya hikâye anlatımına ilişkin sıraladığ 1 yedi temel prensip çerçevesinde incelenmektedir.

\section{Transmedya Hikâye Anlatımı}

Norman (2010), ortak bir hikâye ya da tecrübenin peşinde koşan transmedyayı çoklu medyanın yeniden doğuşu olarak nitelendirmektedir. Bu bağlamda transmedyanın içinde olduğu ticari dünyada farklı kişiler ve farklı şirketler bu deneyimin, karlılığın ve sahipliğin bütününü oluşturan parçalarını ifade etmektedir.

Dijital çağda, popüler kültürdeki güncel örnekleri ile izleyicileri ile buluşan transmedya hikâye anlatımı ${ }^{2}$ bakımından Jenkins (2018: 19-20) içeriğin çeşitli platformlarındaki akışını, farklı medya endüstrilerinin işbirliğini ve istediği eğlence deneyimi arayışıyla her yöne kayabilecek medya izleyicilerinin göçebe davranışını ifade etmek için kullandığı "yakınlaşma" kavramına vurgu yapmaktadır. Bu çerçevede, bireysel tüketicilerin beyinlerinde ve onların diğer kişilerle olan sosyal etkileşiminde kolektif olarak gerçekleştirilen tüketim sürecinde ortaya çıkan "yakınlaşma" ile "kolektif

\footnotetext{
${ }^{1}$ Çalışmada, 19 Mayıs 2018'de gerçekleşen ve resmi sosyal medya hesaplarında “Kraliyet Düğünü” etiketiyle paylaşılan Prens Harry ve Meghan Markle'ın düğününü ifade etmek için kullanılmaktadır.

2 "Transmedya hikâye anlatımı" kavramı ilk kez Henry Jenkins tarafından 2003 yılında yazarın "Technology Review" köşesinde okurla buluşmuş, sonrasında ise "Convergence Culture" isimli kitapta yazarın 'Searching for the Origami Unicorn: The Matrix and Transmedia Storytelling' başlıklı bölümünde kavram detaylı olarak ele alınmıştır (Jenkins 2010b: 944).
} 
zekâ" ve yeni medya sisteminde tüketicileri yeni bilgiler aramaya, dağınık medya içerikleri arasında bağlantılar kurmaya teşvik eden "katılımcı kültür" bağına dikkat çekmektedir.

Farklı medya platformlarında eğlence deneyimlerinin bütünleşik sunumunu ifade eden transmedya hikâye, Heroes ya da Lost gibi bir hikâyenin televizyondan, çizgi roman, web, bilgisayar veya alternatif gerçeklik oyunları, oyuncak gibi farklı ürünlere sıçrayarak sadık tüketicilerin yanısıra yeni tüketicileri de yakalayan bir hikâyedir. Böylece hem tabanda hem de ticari olarak genişleyen anlatısal evrenler yeni bir hikâye anlatım tarzını doğurmaktadır (Jenkins, 2010b).

Transmedya hikâye anlatımı medya kuruluşları için yeni izleyicilere ulaşmak ve daha çok ürün satabilmek için marka genişlemesini sağlayacak bir kaynak olarak kullanılabilir. Aynı zamanda transmedya hikâye anlatımı, belirli bir medya içeriğine ilişkin daha zengin ve karmaşık bir anlatı yapısı oluşturarak hayran kitlesini biraraya getirmek işlevini de yerine getirebilir (Flew, 2017).

\section{Dijital Yerliler ve Transmedya Hikâye Anlatımının Özellikleri}

"Bilgi güçtür" sloganını benimseyen ebeveynlerinin aksine dijital yerliler, sanki dillendirilmemiş yeni mottoları "bilgiyi paylaşmak güçtür" diyebileceğimiz bir nesil olarak edindikleri bilgiyi hemen paylaşmaktan hoşlanmaktadırlar. Bu bağlamda ortaya çıkışından beri web, dijital yerliler tarafından yaşamlarına ve ilgi alanlarına ilişkin bir raporlama aracı olarak kullanılmaktadır. Dijital yerliler için çevrimiçi temasları farklı tarzda da olsa yüz yüze olanlar gibi "gerçek"tir (Prensky, 2012: 97-99).

Çevrimiçi alanda da çevrimdışı yaşamlarında olduğu kadar kendilerini rahat hisseden dijital yerliler birçok dijital göçmenlerden farklı olarak yaşamlarının büyük bölümünü çevrimiçi olarak geçirirler. Çevrimiçi ve çevrimdışını birbirine bağlı olarak değerlendirdikleri bu hibrit yaşamda dijital yerliler, dijital kimliklerini ve gerçek yaşamdaki kimliklerini ayrı olarak görmeksizin (iki, üç ya da daha fazla alanda temsil edilen) tek bir kimliğe sahiptirler (Palfrey ve Gasser, 2011). Dijital yerliler çevrimiçi sosyalleşme ve işbirliği konusunda oldukça tecrübelidir (Meskill ve Anthony, 2010). Yeni medyada dijital yerliler sadece okuyucu, dinleyici veya pasif izleyici olarak kalmamakta yaratıcı yollar kullanarak etkileşim kurmaktadırlar (Palfrey ve Gasser, 2011).

Öykülerin tanıtımında çoklu medyanın kullanımı, birbiriyle etkileşime giren izleyicilerin daha bütünleşik ve katılımcı hale gelmelerini sağlayarak transmedya hikâye anlatımının gücünü arttırabilir. Bunun için ilgili projede; farklı izleyici kitleleri için çeşitli, etkileşimli tüketim yöntemleri sağlayan çoklu medyadan eşzamanlı olarak dağıtımı gerçekleştiren yayın alanları yaratmak ve her bir medyanın tüketici kitlesine özel olarak kişilerin kendisini görünür kılıp masalın içinde kendini var etmesini sağlayacak şekilde içeriği geliştirmek olarak belirtilebilecek iki temel husus ön plana çıkmaktadır (Giovagnoli, 2011: 18-19).

Transmedya hikâye anlatımının; geleneksel ve yeni medya üzerinden birlikte yürüyen melez yapılanması, izleyicinin aktif katılımlarını teşvik ederek onlarla etkileşim kurup öykünün bir parçası haline gelmelerini ve içeriğe katkıda bulunmalarını sağlaması bu anlatı türünün hibrit yaşamı benimseyen ve yeni medyada yaratıcı yöntemlerle etkileşime giren dijital yerlilere hitap eden önemli özellikleri olarak ön plana çıkmaktadır.

Jenkins (2010a) transmedya hikâye anlatımının 7 prensibini şöyle sıralamaktadır:

1) Yayılabilirlik ve derinleşebilirlik

2) Süreklilik ve çeşitlilik

3) Dalmak ve çıkarabilmek

4) Dünya kurmak 
5) Dizisellik

6) Öznellik

7) Performans

Yayılabilirlik, halkın medya içeriğinin sosyal ağlardaki dolaşımına aktif katılma ve bu süreçte ekonomik, kültürel değerini arttırma kapasitesine gönderme yaparken derinleşebilirlik, ilgi alanımıza yönelik şeye ilişkin daha derin dünyalara inebilmeyi ifade etmektedir. Transmedya eğlencelerinin sıkı takipçileri için süreklilik (DC ve Marvel'in süper kahramanları vb.) önemlidir. Çeşitlilik ise olayların ve kahramanların yeni uyarlamalarla sunumundan hayranların zevk almasını sağlar (Jenkins, 2009a). Dalmak ve çıkarabilmek ise transmedya kurgu ve gündelik yaşam deneyimlerimiz arasındaki algılanan ilişkiyi ifade etmektedir. Hikâyenin dünyasına dalan tüketici, hikâyenin belli yönlerini günlük yaşam alanında kaynak olarak kullanmaktadır. Dünya kurmak, tüketicinin anlatılarda temsil edilen dünyalarla doğrudan etkileşime geçmesini (kurgusal mekanlar için seyahat afişlerinin üretime tanık olmak vb.) ve bunları kendi yaşamı ile kesişen gerçek mekanlar olarak ele almasını sağlamaktadır. Dizisellik bağlamında transmedya hikâye anlatımı, anlamlı ve ilgi çekici hikâye parçalarının aynı ortamdaki çoklu katmanlarını değil çoklu medya sistemleri arasındaki dağılımını gösteren hiperbolik bir sürümdür. Öznellik boyutu, transmedya uzantılarda kurgusal dünyanın keşfedilmemiş boyutlarına-örneğin hikâyenin ikincil karakterlerinin deneyimlerine ve bakışaçılarına- odaklanma yoluyla tüketicilere farklı öznel deneyimlerini karşılaştırma olanağı sağlanmasını ifade etmektedir. Performans, hayranların hikâyeye çeşitli yollarla aktif katılımını (çevrimiçi paylaşım, mekân tasarımı, senaryo oluşturma vb.) göstermektedir (Jenkins, 2009b).

UNESCO (2011) tarafından dijital yerlilerin davranış tarzlarını açıklamak için 3 temel özellik üzerinde durulmaktadır. Bunlar; yeni bilgilere erişmek, ağ kurmak ve ortak zekayı geliştirmek şeklinde sıralanmaktadır. Jenkins' in (2010a) sıraladığ 7 temel prensip çerçevesinde ele aldığımızda transmedya hikâye anlatımının dijital yerlilerin bu 3 temel özelliği ile kesişen noktaları bulunmaktadır. Yayılabilirlik ve derinleşebilirlik yeni bilgiye erişim konusunda dijital yerlilerin farklı medya platformlarındaki dolaşımına gönderme yapmaktadır. Dizisellik ve öznellik ise hikâyenin farklı medyadaki, farklı boyutlarına kişisel dokunuşlarını yapan dijital yerlilerin ortak zekayı inşasına katkı sağlayan süreçler olarak karşımıza çıkmaktadır. Dalmak ve çıkarabilmek ise dijital yerlilerin yeni bilgilere erişiminde, performans ise kurulan ağın genişletilmesinde kullanılan özellikler olarak karşılık bulmaktadır. Yine Jenkins'in (2018) transmedya hikaye anlatımı bağlamında vurgu yaptığı "yakınlaşma", "kolektif zeka" ve "katılımcı kültür" kavramları ve yukarıda sıraladığımız; çevrimiçi sosyalleşme ve işbirliği (Meskill ve Anthony, 2010), bilgi paylaşımını güç olarak görmek (Prensky, 2012), yeni medyada aktif bir şekilde etkileşim kurmak (Palfrey ve Gasser, 2011), medya içeriğini geliştirmek (Giovagnoli, 2011) gibi dijital yerlilere atfedilen çeşitli özellikler transmedya hikaye anlatımı yöntemi ile dijital yerliler arasındaki bağı daha görünür kılmaktadır.

\section{Yöntem}

Çalışmada nitel araştırma türlerinden örnek olay incelemesi yöntemi kullanılmıştır. Örnek olay incelemesinde (vaka çalışması), bazen bir grubu temsil eden bir birey ele alınabileceği gibi daha çok belirli bir durum, olay, program veya aktivite gibi bir olguya odaklanılmaktadır. Araştırılan olgu kendi doğal bağlamı ve zaman-mekân sınırlaması içinde incelenir. Çeşitli bilgi kaynaklarına dayanan örnek olay incelemesi tamamen betimleyicidir. Örnek olay incelemesinde; internetten elde edilen belgeleri, özel ve kamu kayıtlarını, fiziksel kanıtlar ve kendisi tarafından oluşturulan araçları araştırmacı döküman olarak kullanabilir (Hancock ve Algozzine, 2006). Bu çalışmada da örnek olay incelemesinde kraliyet düğününe ilişkin haberleri içeren internet kaynakları kullanılmıştır. Örnek olay incelemesinde araştırılan konuya ilişkin "neden" ve "nasıl” sorularına yanıt aranır (Yin. 1994). Bu çalışmada ise; "Kraliyet Dügünü'nün medyadaki temsili neden transmedya hikâye anlatımı kapsamında değerlendirilebilir?" sorusuna yanıt aranmaktadır. Örnek olay incelemesi belirli tipte kanıt kullanımını 
gerektirmez. Örnek olay incelemesi nicel ya da nitel nitelikte kanıtlar kullanılabilir. Bunlar; saha çalışması, arşiv kayıtları, sözlü raporlar, gözlemler veya bunların kombinasyonundan oluşabilir (Yin, 1981: 58).

\section{Olayı}

Transmedya Hikâye Anlatımı Bağlamında Kraliyet Markası: Kraliyet Düğünü Örnek

Miras turizminin bir alt kümesi olarak kraliyet turizmi, belirli bir monarşideki ya da genel olarak monarşi kurumundaki insanların geçmiş, şimdi ve geleceğe dair bağlarının keşfedilmesini ya da sorgulanmasını ifade etmektedir. Kraliyet etkinliklerini, sergilerini ve deneyimlerini tüketen çoğu turist genellikle estetik zevk, aydınlanma, seçkinlik ve/veya eğlence tutkularını tatmin etmeyi, kendi yurttaşlık, soy, etnik kimlik ve toplumsal cinsiyetlerine dair belirli bağlantılar kurabilmeyi amaçlamaktadır. Her sene milyonlarca meraklı, yüzyılı aşan kraliyet öyküsü ile ilişkilendirilen; kale, sergi, hediyelik eşya mağazaları, müze, park, saray, gemi vb. alanları ziyaret etmektedir (Otnes ve Maclaran, 2015:194-195). Brand Finance'in araştırması İngiliz Kraliyet Ailesi’nin marka değerini 60 milyar sterlinin üzerinde olarak belirtirken Kraliçe ve ailesinin Birleşik Krallık ekonomisine y1llık katkısını 1,8 milyar sterlin şeklinde açıklamaktadır (NTV, 2017). Prens Harry ve Meghan çifti Kraliyet markasının ve ailesinin yeni çifti olarak dünya basınından yoğun ilgi görmektedir. Kraliyet dügünü, kraliyet markası ile ilişkilendirilen bir peri masalı anlatımı niteliğindedir. Bu masalın medyadaki temsilinin transmedya hikâye anlatımı bağlamında incelenecek çeşitli boyutları bulunmaktadır.

Marka değerleme ve strateji danışmanlığında dünya öncüsü olan Brand Finance'in yaptığı analiz Kraliyet dügününün İngiliz ekonomisine getirisinin 1.05 milyar sterlin olduğunu göstermektedir. $\mathrm{Bu}$ toplam tutarın 300 milyon sterlinlik kısmını ise Windsor'dan yapılan canlı yayının beklenen reklam değeri denkliği (AVE), televizyon yayını, internet yayını, internet ve basılı medya ayağını kapsayan halkla ilişkiler değeri (PR Value) oluşturmaktadır (Brand Finance, 2018).

\section{Bulgular}

Dügünün ardından Kraliçe tarafindan kendilerine Sussex Dükü ve Sussex Düşesi ünvanları verilen Prens Harry ve Meghan Markle'ın Kraliyet düğününe ilişkin haberler geniş bir şekilde ve farklı boyutlarıyla çeşitli medya platformlarında yer alarak dünya çapında çok sayıda izleyiciye ulaşmıştır. Transmedya hikâye anlatımında Jenkins (2018: 42), yaratılan dünyanın bütününü deneyimleyebilmek için avcı ve toplayıcı rollerine giren tüketicilerin medya kanalları arasında hikâyenin parçalarının izini sürdüklerini belirtmektedir. Takipçilerine bu anlamda oldukça zengin bir malzeme sunan "Kraliyet Dügünü" de basılı, görsel, işitsel olarak geleneksel medya ve yeni medya üzerinden çoklu bir yapıda temsil edilmiştir.

Düğünün öncesinde RoyalWedding etiketine saatte 8 tweet atıllrken, düğün öncesi son 3 ay içinde \#RoyalWedding, Meghan Markle ve Prens Harry kelimelerini içeren yaklaşık 36.600 tweet atıldığı belirtilmektedir (TLC, 2018). Çift, "sussexroyal" isimli instagram hesabından dügünlerinde çekilen fotoğraflarını ve "Her biriniz bugünü daha da anlamlı kıldınız" notu ile de videolarını paylaşmıştır (BBC, 2019).

Jenkins (2018: 144-145) transmedya hikâye anlatımında her ürünü (film, roman, oyuncak vb.) bir bütün olarak franchisea giriş noktası olarak görür. Meghan Markle ve Prens Harry'nin düğününe ilişkin de belgesel, film, hediyelik eşya gibi farklı ürünlerin hazırlandığı görülmektedir.

Düğüne ilişkin National Geographic tarafından hazırlanan “Operasyon Kraliyet Düğünü” isimli belgeselin Natgeotv'de webisode olarak yayını bulunmaktadır (www.natgeotv.com/tr).

Modern peri masalı olarak nitelenen Meghan Markle ve Prens Harry'nin aşk hikayesi 2019 yapımı "Harry \& Meghan: A Royal Romance" adlı televizyon filmiyle sinematografik anlamda gündeme gelmiştir. Filmde çiftin ilişkilerinin ve evliliklerinin perde arkası, ailelerinin ve kültürlerinin 
bir araya gelişi, gelenekleri gibi konular ele alınmaktadır (Esquire, 2019). Bu filmin öncesinde 2018'de çiftin ve yakınlarının röportajlarını içeren "Harry and Meghan: A Windsor Wedding" isimli belgesel türündeki yapım, yine 2018'de İngiliz kraliyet düğün tarihini ve çift için güncellenen geleneklerini anlatan "Harry and Meghan: Royal Rebels" isimli belgesel yapım, 2017'de ise çiftin ilişkilerinin yanısıra Meghan'ın özel yaşamı, oyunculuk kariyeri gibi detaylara da yer veren "Prince Harry and Meghan: Truly, Madly, Deeply" başlıklı belgesel yapım göze çarpmaktadır (www.imdb.com).

Markle'ın 15 yaşında İngiltere'de Buckingham Sarayı önünde çekilen tatil fotoğrafi "Hatıra fotoğrafı çektirdiği sarayın gelini oluyor" yorumları ile sosyal medyada paylaşım rekoru kırmıştır (Haber Turk, 2018).

Dügünden bir süre sonra, Harry ve Meghan çiftinin düğün fotoğrafçısı Alexi Lubomirski'nin bilgisayarındaki dosyalar siber korsanlar tarafından hacklenmiş, düğünden karelerin (Çiftin beğenmedikleri için kamuoyuyla paylaşmak istemedikleri fotoğraflar da) sosyal medyaya sızdırılmıştır. İngiliz Kraliyeti ise olaya ilişkin soruşturma başlatıldığını duyurmuştur (Sabah, 2019).

Çoklu kameralar ve bölünmüş ekranlar aracılı̆̆ıyla televizyon aynı anda Kraliyet Düğünün her yerinde (saray, kilise, düğün güzergahı vb.) olamayacak izleyicilere törenin farklı anlarını birlikte sunmaktadır. Bu süreçte biraraya getirilmek zorunda olan seremonin farklı unsurları birer aktör (saray muhafızı, din adamı, polis, izleyici) haline gelmektedir (Katz ve Dayan, 1985: 311). Yeni teknolojiler günümüzde televizyonlara farklı uygulamalar sunma imkânı tanımaktadır. ABC News Prens Harry ve Meghan'ın kraliyet dügünü kutlamak için seyircilerine "Kraliyet Düğünü Artırılmış Gerçeklik Deneyimi" (The Royal Wedding AR Experience) başlığı ile Windsor Kalesi'nin ikonik sembollerini artırılmış gerçeklik ile izleyicilerine ulaştırmıştır. ABC News IOS uygulaması da bulunan 3D (3 boyutlu) Kraliyet vagonu veya 3D Kraliçenin muhafizları ile kullanıcılar poz verip fotoğraflarını çekme fırsatı yakalamaktadır (ABC News, 2018). Jenkins (2018: 145) iyi bir transmedya franchise içeriği, farklı medyada kısmen farklı bir şekilde sunulan, çeşitli hayran gruplarını kendine çekmek ve onların ilgililerini sürdürmek adına yeni deneyimler sunan çalışmalar olarak özetlemektedir. Dügünü farklı bir deneyim boyutuyla hayranlarına sunan ABC News' in "Kraliyet Düğünü Artırılmış Gerçeklik Deneyimi”" uygulaması da iyi bir transmedya franchise örneği olarak karşımıza çıkmaktadır.

Düğün katılımcıları için hazırlanan ve içinde kurabiye, anma mıknatısı, Windsor Castle suyu, büyük bir çikolata madalyonu gibi ürünlerin yer aldığı düğün hediyesi çantalarının açık arttırmayla ebay internet sitesi üzerinden satıldığı görülmektedir. Satıcılardan birinin: "İngiltere ve kraliyet ailesi için ve çok bu özel günü kutlamak için tarihi ve hatıralık bir parça satın al" ifadesi ile satışa koyduğu ürünler (IHHA, 2018) kraliyet düğününde fiziksel olarak yer almayan ancak hikâyenin bir parçası olmak isteyenlere bir fırsat sunmaktadır. Ayrıca bu resmi düğün hediyesi çantasının yanısıra Kraliyet'in onayından geçerek hazırlanan kartonetler, tuzluklar, yastıklar, bayraklar, tabak takımları, fincan setleri, maskeler, şapkalar, mug'lar, posterler, pullar, hatıra paraları gibi çeşitli hediyelik eşyaların da yerel esnaf tarafından satışa sunulduğu görülmektedir (Barlas, 2018).

Dügüne katılan davetliler arasında en dikkat çeken isimlerden biri Prens Harry'nin 7 yıl ilişki yaşadığı eski sevgilisi Chelsy Davy olmuştur. Dügünde üzüntüsü sebebiyle Davy'nin sürekli değişen yüz ifadeleri sosyal medyada binlerce kişinin paylaşımı ile yer bulmuştur (www.haberler.com). Davy'e ilişkin sosyal medyada yapılan bu paylaşımlar, transmedya hikâye anlatımı çerçevesinde değerlendirildiğinde hikâyenin ikincil karakterlerine odaklanma özelliğini temsil etmektedir.

Dügüne katılan davetliler kadar basında adından söz ettiren bir başka isim de gelinin babası Thomas Markle olmuştur. Dügün öncesi törene katılıp katılmayacağı konusu merak uyandıran babasına ilişkin Meghan Markle Twitter'daki Kensington Sarayı hesabından 17 Mayıs 2018 tarihinde bir mesaj yayınlamış ve babasının sağlık sebeplerinden ötürü düğüne katılamayacağını duyurmuştur (www.radiotimes.com). 
Bazı markaların Kraliyet Düğüne özel çeşitli kampanyalar yaptığı görülmektedir. Düğün günü Toronto'dan (Prens Harry ve Meghan Markle'ın bir süre birlikte yaşadığı kent) İngiltere'ye yapılan sefer için Meghan ve Harry isimli mürettabatı seçen, bu seferde yolculara şampanya ve İngiliz kekleri ikram eden, Harry, Meghan veya Megan isimli tüm müşterilerini havayolunun birinci sınıf salonunu kullanmaya davet eden British Airways, çiftin yüzlerini içeren sınırlı sayıda ürünü piyasaya sunan Avusturyalı şeker markası Pez bu markalar arasındadır (Hürriyet, 2018). KFC ise Prens Harry'nin evde akşam yemeği sırasında tavuk yerken evlilik teklif ettiğini söylemesinin üzerine İngiliz porseleninden yapılan sınırlı sayıda KFC kovası Kentucky Fine China’yı satışa sunmuştur. Marks \& Spencer markası ilginç bir kampanya yaparak bugüne özel olarak adını "Markle \& Sparkle" olarak değiştirmiştir. Kampanya birçok kullanıcının \#markleandsparkle hashtag'iyle yaptığı paylaşımlarla sosyal medyada da yer bulmuştur. Lego, büyük günü 39,960 adet Lego'dan oluşan bir Winsdor Kalesi minyatürü oluşturarak kutlamıştır (Bayındır, 2018). The Ashton-Drake Galleries tarafından hazırlanan Prens Harry ve Meghan'ın düğün kıyafetleri içinde porselen oyuncak bebeklerinin internet üzerinden satışa sunulduğu görülmektedir (www.ashtondrake.com).

Peri masalı vurgusu ile ön plana çıkan düğünde yeni evli çiftin (halkı selamlarken, öpüşürken, merdivenlerden inerken) ve konukların (giysileri) çeşitli enstantaneleri, Disney masallarındaki animasyon görüntülerle eşleştirilerek sosyal medyada yan yana karelerde yer almıştır. Düğüne espirili bir bakış yaklaşım sergileyen bu kareler aynı zamanda masalların gerçek olabileceği mesajını da içinde barındırmaktadır (NTV, 2018).

Dügünün 1.y1ldönümünde kraliyet çifti Sussex Düşü ve Düşesi düğünden daha önce yayınlanmayan bazı fotoğrafları instagram hesapları üzerinden takipçileri ile paylaşmıştır (Sager, 2019).

Kraliyet dügününe ünlü isimlerin (George ve Amanda Clooney, David ve Victoria Beckham, James Blunt, Elton Jonh vb.) yanısıra halktan aralarında kraliyet ailesine hizmet edenler, vakıf çalışanları, çocuklar, Windsor sakinlerinden bir kısmının bulunduğu 2 bin 640 kişi davet edildi (Samar, 2018).

Sky News, görüntü ve video analizi sağlayan Amazon Rekognition uygulaması aracıllğıyla kraliyet dügününe katılan ünlü kişileri yüz okuma sistemi ile kişi görüntülendiği anda tespit edip bu kişilerin isimlerini ve bazı bilgilerini yayında izleyicilerle paylaşmıştır (http://www.wikitrend.org).

Bulguları Tablo-1'de özetlenen çalışma, kraliyet dügünün geleneksel ve yeni medyadaki temsili bakımından transmedya hikâye anlatımının temel prensiplerini taşıdığını göstermektedir. 
Tablo-1: Transmedya Hikâye Anlatımı Prensipleri Bağlamında Kraliyet Dügünün Medyadaki Temsilinin Değerlendirilmesi

\begin{tabular}{|c|c|}
\hline $\begin{array}{l}\text { Transmedya } \\
\text { Hikâye } \\
\text { Anlatımının } \\
7 \text { Temel Prensibi } \\
\end{array}$ & $\begin{array}{l}\text { Kraliyet Düğünün Medyadaki Temsilinin Transmedya Hikâye Anlatımı } \\
\text { Prensiplerine İlişkin Görünümü }\end{array}$ \\
\hline $\begin{array}{c}\text { Yayılabilirlik } \\
\text { ve } \\
\text { Derinleşebilirlik }\end{array}$ & $\begin{array}{l}\text { - Kraliyet Düğününün farklı medya platformlarında (tv, radyo, internet) yer alması. } \\
\text { - Kraliyet Düğünü öncesi son } 3 \text { ayda \#RoyalWedding, Meghan Markle ve Prens Harry } \\
\text { kelimelerini içeren yaklaşı } 36.600 \text { tweet atılması } \\
\text { - Çiftin "sussexroyal" isimli instagram hesabından, düğünlerinde çekilen fotoğraflarını ve } \\
\text { "Her biriniz bugünü daha da anlamlı kıldınız" notu ile de videolarını paylaşması } \\
\text { - Sky News'in, görüntü ve video analizi sağlayan Amazon Rekognition uygulaması } \\
\text { aracillğıyla kraliyet düğününe katıllan ünlü kişileri yüz okuma sistemi ile tespit edip bu } \\
\text { kişilerin isimlerini ve bazı bilgilerini yayında izleyicilerle paylaşması }\end{array}$ \\
\hline $\begin{array}{l}\text { Süreklilik } \\
\text { ve çeşitlilik }\end{array}$ & $\begin{array}{l}\text { - Kraliyet Düğününe ilişkin izleyen yıllarda (2018-2019) farklı televizyon belgesellerin } \\
\text { gösterime girmesi. } \\
\text { - Natgeotv'nin internet sayfasında “Operasyon Kraliyet Düğünü” belgeselinden webisode } \\
\text { yayınlanması }\end{array}$ \\
\hline $\begin{array}{c}\text { Dalmak } \\
\text { ve çıarabilmek }\end{array}$ & $\begin{array}{l}\text { - e-bay internet sitesi üzerinden açık arttırmayla satılan Kraliyet düğ̈̈n hediyesi } \\
\text { çantalarının, hayranlarına hikayenin parçalarını gündelik hayatının parçası haline getirme } \\
\text { firsatı sunması } \\
\text { - Kraliyet düğünü için yerel esnaftarafindan hazırlanan hediyelik eşyaların (kartonet, tuzluk, yastık, } \\
\text { bayrak, tabak takımı, fincan seti, maske, şapka, mug, poster, pul, hatıra para vb) satışa sunulması } \\
\text { - British Airways'in düğ̈̈n günü Toronto'dan (Prens Harry ve Meghan Markle'ın bir süre } \\
\text { birlikte yaşadığı kent) İngiltere'ye yapılan seferinde Meghan ve Harry isimli mürettabatı } \\
\text { seçmesi, bu seferde yolculara şampanya ve İngiliz kekleri ikram etmesi, Harry, Meghan } \\
\text { veya Megan isimli tüm müşterilerini havayolunun birinci sınıf salonunu kullanmaya davet } \\
\text { etmesi } \\
\text { - KFC markasının Prens Harry'nin tavuk yerken yaptığı evlilik teklifine itafen İngiliz } \\
\text { porseleninden yapılan sınırlı sayıda KFC kovası Kentucky Fine China'yı satışa sunması } \\
\text { - The Ashton-Drake Galleries tarafindan hazırlanan Prens Harry ve Meghan'ın } \\
\text { düğünlerini temsilen porselen oyuncak bebeklerinin internet üzerinden satışa sunulması }\end{array}$ \\
\hline Dünya kurmak & $\begin{array}{l}\text { - ABC News IOS uygulaması aracılı̆ğyla 3D (3 boyutlu) Kraliyet vagonu veya 3D } \\
\text { Kraliçenin muhafizları ile fotoğraf çekmek } \\
\text { - Lego'nun Kraliyet Düğününü } 39,960 \text { adet Lego'dan oluşan bir Winsdor Kalesi } \\
\text { minyatürü oluşturarak kutlaması }\end{array}$ \\
\hline Dizisellik & $\begin{array}{l}\text { - "Sussex Royal" isimli resmi Instagram hesabından Kraliyet Dügünün yıldönümünde } \\
\text { daha önce yayınlanmayan fotoğrafların paylaşılması }\end{array}$ \\
\hline Öznellik & $\begin{array}{l}\text { - Prens Harry'nin eski sevgilisi Chelsy Davy'in düğünde sürekli değişen yüz ifadelerinin } \\
\text { sosyal medyada binlerce kişi tarafindan paylaşılması ve yorumlanması } \\
\text { - Sosyal medyada yeni evli çiftin (halkı selamlarken, öpüşürken, merdivenlerden inerken) } \\
\text { ve konukların (giysileri) çeşitli enstantanelerinin Disney masallarındaki animasyon } \\
\text { görüntülerle eşleştirilerek sunulması } \\
\text { - Gelinin babas Thomas Markle'’n düğün öncesi medyada çeşitli haberlerle gündeme } \\
\text { gelmesi ve kamuoyu tarafindan düğüne katıllı katılmayacağı merak konusu olan babasına } \\
\text { ilişskin Meghan Markle'ın Twitter'daki Kensington Sarayı hesabından } 17 \text { Mayıs } 2018 \\
\text { tarihinde bir mesaj yayınlayarak sağlı sebeplerinden ötürü düğüne katıllamayacağın1 } \\
\text { duyurması }\end{array}$ \\
\hline Performans & $\begin{array}{l}\text { - Fotoğraf̧ıı Alexi Lubomirski'nin bilgisayarındaki düğün fotoğraflarının siber korsanlar } \\
\text { tarafindan hacklenerek sosyal medyada paylaşılması } \\
\text { - Meghan Markle'ın } 15 \text { yaşındayken İngiltere'de Buckingham Sarayı önünde çekilen tatil } \\
\text { fotoğrafının "Hatıra fotoğrafı çektirdiği sarayın gelini oluyor" yorumları ile sosyal } \\
\text { medyada paylaşım rekoru kırması }\end{array}$ \\
\hline
\end{tabular}




\section{Sonuç}

Dijital yerlilerin marka ile bağ kurmasında önemli bir yöntem haline gelen transmedya hikâye anlatımı günümüzde farklı örneklerle karşımıza çıkmaktadır. Düğün, tören vb. özel günlerle sıkça gündeme gelen Kraliyet Markası medyadaki temsili aracılığıyla popüler kültürle yakın ilişkidedir. Bu bağlamda Kraliyet ailesinin üyeleri popüler kültürde temsil edilen ve birçok kişinin yaşamına dahil ettiği karakterler haline gelmektedir. Jenkins (2018: 349) bireylerin popüler kültür için duydukları tutkuyu; bu kültürün karakterlerini benimseme, hikayelerini yaşamlarımıza kaynaştırma, üzerinde tekrar çalışarak onları kendimizin kılma şeklinde ifade etmektedir.

İngiliz Kraliyet Ailesi Markasının son dönemde gündemde olan çifti Prens Harry ve Meghan'ın (Sussex Düşü ve Düssesi) Kraliyet Dügünü; hazırlık aşaması, düğün günü ve dügün sonrası periyotta çeşitli haberlerle geleneksel ve yeni medyada temsili bağlamında incelendiğinde transmedya hikâye anlatımını örneklemektedir. Kraliyet Dügünü; tv, internet, radyo gibi farklı mecralardan töreni takip eden dünya çapındaki milyarlarca kişinin şahitliğinde hayalleri gerçeğe taşıyan bir anlatı görünümündedir. Bu bağlamda, İngiliz Kraliyet Markasına sosyal, ekonomik ve kültürel açıdan çok yönlü katkıları bulunan Kraliyet düğünü, izleyiciye aktarımında çoklu medyanın kullanıldığı, sıkça vurgulandığı tanımıyla modern bir peri masalı niteliğindedir. Dijital yerlilerin özellikleri ve yeni medyaya büyük önem atfeden yaşam tarzları ile kesişim noktaları olan transmedya hikâye anlatımı bağlamında Jenkins'in sıraladığı 7 temel prensip çerçevesinde ele alınan Kraliyet Düğününün transmedya hikâye anlatımına ilişkin sıralanan bu özellikleri taşıdığı görülmektedir.

\section{KAYNAKÇA}

Giovagnoli, M. (2011), Transmedia Storytelling: Imagery, Shapes and Techniques, Lulu.com

Hancock, D. R. ve Algozzine, B. (2006), Doing Case Study Research, Teachers College Press

Jenkins, H. (2010b), Transmedia Storytelling and Entertainment: An annotated syllabus, Continuum, 24:6, 943-958

Jenkins, H. (2018), “Cesur Yeni Medya”: Teknolojiler ve Hayran Kültürü, N. Yeğengil (Çev.), İstanbul: İletişim Yayınları

Katz, E. ve Dayan, D. (1985), Media Events: On The Experience Of Not Being There, Religion 15, 305314

Meskill, C. ve Anthony, N. (2010), Teaching Languages Online, Multilingual Matters

Norman, D. A. (2010), "THE WAY I SEE IT The transmedia design challenge: technology that is pleasurable and satisfying." interactions 17.1, 12-15.

Otnes, C. C. ve Maclaran, P. (2015), Royal Fever: The British Monarchy in Consumer Culture, Univ of California Press

Palfrey, J. G. ve Gasser, U. (2011), Born Digital: Understanding the First Generation of Digital Natives, ReadHowYouWant. com.

Prensky, M. (2012), From Digital Natives to Digital Wisdom, Corwin Press

UNESCO (2011), “Digital Natives: How Do They Learn? How to Teach Them?, IITE Policy Brief

Yin, R. K. (1981), The Case Study Crisis: Some Answers, Administrative Science Quarterly, Vol. 26, No. 1 (Mar., 1981), 58-65

Yin, R.K. (1994) Case study research: design and methods. 2nd edition. Thousand Oaks, CA: Sage. 


\section{Elektronik Kaynaklar}

ABC News (2018, 14 Mayıs), The royal wedding augmented reality experience, Erişim adresi: https://abcnews.go.com/US/royal-wedding-augmented-reality-experience/story?id=55071238, Erişim tarihi: 10.06.2019

Barlas, H. C. (2018, 19 Mayıs), Meghan Markle ve Prens Harry’nin düğününün detayları, Erişim adresi: https://www.sozcu.com.tr/hayatim/son-moda/meghan-markle-ve-prens-harrynin-dugununundetaylari/, Erişim tarihi: 10.06.2019

Bayındır, M. (2018, 21 Mayıs), Royal Wedding: Markalar nasıl yaklaştı?, Campaign Türkiye, Erişim adresi: https://www.campaigntr.com/royal-wedding-markalar-nasil-yaklasti/, Erişim adresi: 09.06.2019

BBC (2019, 19 Mayıs), Prens Harry ve Meghan Markle evlilik yıl dönümlerinde yeni düğün fotoğrafları paylaşt1, Erişim adresi: https://www.bbc.com/turkce/haberler-dunya-48326213, Erişim tarihi: 10.06.2019

Brand Finance (2018, 17 Mayıs), Brand Finance Press Release, Erişim adresi: https://brandfinance.com/images/upload/brand_finance_press_release_royal_wedding_to_boo st_british_economy_by_1_billion.pdf, Erişim tarihi: 10.06.2019

Esquire (2019, 27 Mart), Kraliyetin romantik filmi: Harry \& Meghan, Erişim adresi: http://www.esquire.com.tr/ekstra/kultur-sanat/2019/03/27/kraliyetin-romantik-filmi-harrymeghan, Erişim tarihi: 12.06.2019

Flew, T. (2017), Media Convergence, Encylopaedia Britannica, Erişim adresi: https://www.britannica.com/topic/media-convergence, Erişim tarihi: 10.06.2019

https://www.ashtondrake.com/products/301652008_meghan-markle-bride-doll-with-swarovski.html, Erişim tarihi: 01.06. 2019

https://www.imdb.com/title/tt7587122/?ref_=tt_rec_tt, Erişim tarihi: 12.06.2019

http://www.wikitrend.org/tv-viewers-learned-who-royal-wedding-attendees-are-facial-recognition-ai, Erişim tarihi: 12.06.2019

https://www.radiotimes.com/news/tv/2018-05-19/how-to-watch-the-royal-wedding-of-prince-harryand-meghan-markle/, Erişim tarihi: 08.06.2019

https://www.natgeotv.com/tr/belgeseller/natgeopeople/operasyon-kraliyet-dugunu/videolar/webisodeoperasyon-kraliyet-dugunu-1, Erişim tarihi: 12.06.2019

https://www.haberler.com/prens-harry-nin-eski-sevgilisi-teselliyi-yeni-10890312-haberi/, Erişim tarihi: 12.06.2019

Haber Turk (2018), Prens Harry ve Meghan Markle, evlenir evlenmez Suxxes dükü ve düşesi olacak!, Erişim adresi: https://www.haberturk.com/prens-harry-ve-meghan-markle-bugun-evleniyor1974345, Erişim tarihi: 05.06.2019

Hürriyet (2018, 19 Mayıs), Düğün bahane gelir şahane, Erişim adresi: http://www.hurriyet.com.tr/ekonomi/dugun-bahane-gelir-sahane-40842341, Erişim tarihi: 07.06 .2019

İHA (2018, 23 Mayıs), Kraliyet'in düğün hediyesi satışa çıkarıldı, Erişim adresi: https://www.iha.com.tr/haber-kraliyetin-dugun-hediyesi-satisa-cikarildi-726972/, Erişim tarihi: 09.06.2019 
Jenkins, H. (2009a), The Revenge of the Origami Unicorn: Seven Principles of Transmedia Storytelling (Well, Two Actually. Five More on Friday), Erişim adresi: http://henryjenkins.org/blog/2009/12/the_revenge_of_the_origami_uni.html, Erişim tarihi: 12.06.2019

Jenkins, H. (2009b), Revenge of the Origami Unicorn: The Remaining Four Principles of Transmedia Storytelling, Erișim adresi: http://henryjenkins.org/blog/2009/12/revenge_of_the_origami_unicorn.html, Erişim tarihi: 19.06.2019

Jenkins, H. (2010a), Transmedia Education: the 7 Principles Revisited, Erişim adresi: http://henryjenkins.org/blog/2010/06/transmedia_education_the_7_pri.html Erişim tarihi: 12.06.2019

NTV (2017, 24 Kasım), İngiliz Kraliyet Ailesi'nin değeri 60 milyar sterlinden fazla, Erişim adresi: https://www.ntv.com.tr/ekonomi/ingiliz-kraliyet-ailesinin-degeri-60-milyar-sterlindenfazla,qptD55pX10ahKyXrDr1qgw, Erişim tarihi: 10.06.2019

NTV (2018, 23 Mayıs), Sosyal medyada kraliyet düğününe verilen komik tepkiler, Erişim adresi: https://www.ntv.com.tr/galeri/yasam/sosyal-medyada-kraliyet-dugunune-verilen-komiktepkiler,b2nizVdJQ0yFtdxP8HtJoA/Rqt3ntn67kSI0vHodk5Aew, Erişim tarihi: 12.06.2019

Sabah (2019, 9 Haziran), Kraliyet düğününün fotoğraflarını hacklediler, Erişim adresi: https://www.sabah.com.tr/dunya/2019/06/09/kraliyet-dugununun-fotograflarinihacklediler?utm_source=widget_haber, Erişim tarihi: 20.06.2019

Sager, J. (2019, 19 Mayıs), Prince Harry, Meghan Markle Release Unseen Royal Wedding Photos for Anniversary, Fox News, Erişim adresi: https://www.foxnews.com/entertainment/prince-harrymeghan-markle-royal-wedding-anniversary, Erişim tarihi: 12.06.2019

Samar, K. (2018, 19 Mayıs), Kraliyet Düğünü'nün Ünlü Konukları, Euronews, Erişim adresi: https://tr.euronews.com/2018/05/19/kraliyet-dugunu-nun-unlu-konuklar-, Erişim tarihi: 10.06.2019

TLC (2018, 18 Mayıs), Kraliyet Düğününe Dair Merak Edilen Her Şey, Erişim adresi: https://www.tlctv.com.tr/kendini-daha-iyi-hissetmen-icin-10-oneri, Erişim tarihi: 12.06.2019 